\title{
電解コンデンサの放電を利用した 大型点溶接機の試作研究
}

\author{
大蒋 郁夫林初芝武美** \\ On the Study of a Powerful Spot Welder which is \\ Tentatively Made by Using Electrolytic Condenser \\ to Store and Discharge Energy
}

By Ikuo Otsuka and Takemi Hatsusiba

\begin{abstract}
For the purpose of spot welding of aluminum plate of appreciable thickness, we have made a powerful spot welder using huge electrolytic capacitors $(125,000 \mu \mathrm{F}, 500$ volts dc.). This welder being $40 \mathrm{KVA}$ in capacity, a constant charging current system with thyratron control is used to minimize the loss due to charging resistor and to shorten the period of charging large capcitance.

Spot welding is carried out in a cycle per two seconds and welding current continues about 0.1 seconds. About $150 \mathrm{KA}$ are used to get sound welds of $4.0 \mathrm{~mm}, 2 \mathrm{~S}$ aluminum sheets.
\end{abstract}

\section{1.はしがき}

アルミニウム乱よびその合金の点溶接にはコンデンサ 放電による静電蓄勢型の点溶接機を用いるとよい結果が 得られる.すなわちアルミニウムのように電気的, 熱的 伝導性のよい金属を点溶接する場合には瞬間的に大電流 を通す必要があり、コンデンサ放電を利用することはこ の目的镅合するあのである.

理化学研究所以話いて1952年以来開発された電解コン デンサの放電を利用した点溶接機は，電解コンデンサが 小型で大容量が得られ，また従来の高王コンデンサを使 ったものにくらべ低压のため取扱が容易で充電䒾置など 6比較的簡単であり，点溶接機として入力容量が少いな どの経斉性や溶接品質の向上, 均一化などの信頼度, 機 械の耐久性などから多く使用されるようになった。

この報告はアルミニウム特よびその合金 $3 \mathrm{~mm}$ 厚以上 の厚板を点溶接するため電解コンデンサを使って試作 された点溶機の設計招よび試作結果についての報告であ る.

\section{2. 溶接機械および回路の設計}

コンデンサ型点溶接機の電気回路は大別して電源部之 溶接部とにわけられる.すなわら電源部はコンデンサと

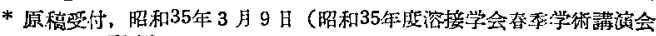
に打以て呚表)

** 正員, 理化学研究所 Member, The Institute of Physical and Chemical Research.
充電回路, 溶接部は溶接トランススよび溶接電流回路よ 電極とからなる.

\section{電源部の構成}

この点溶接機は厚板用としてコンデンサの容量をふや し蓄積エネルギーの増加をはかった，そのため大容量の 電解コンデンサを規定の電任まで方電するのに従来使わ れている一定電王の電源による充電方法では充電時間が 長くなり充電電流も大きく回路の使用效率も悪いので新 たにサイラトロン（熱陰極整子制御放電管）6本による 三相全波整流の定電流充電方式によって充電効率をあげ 充電時間の短縮をはかった。

すなわち従来の充電方法では電源電圧が一定であるた めコンデンサ電圧の上蒋にしたがい電源とコンデンサと の電压差が少くなり，そのため充電電流はしだいに娍少 する、したがって充電時間は長くなる。また整流管は許 容電流で制限された最初の電流值により規定されるので 使用率は悪く充電回路の抵抗損失も大き加た. この点 溶接機に使った新たな充電方式では充電されたコンデン サ電圧の上昇分だけ電圧がサイラトロンのプレートル加 わるようにして電王差を一定に保ら定電流充電が行われ

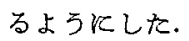

実際の回路は原理図《示すように制御サイラトロン2D 21を使用して充電用サイラトロン6G24または6G21(C6J) のグリッド回路でその点火位相を制街した。すなわち Fig. 1 でサイラトロンは位相角 $\theta_{1}$ で動作しプレート電 压 $e_{p 1}$ で電流が流れる。この電流によってコンデンサは 
$E_{2}$ 飞充電され，次飞同一電流を流すとは $e_{p 2}-E_{2}=e_{p_{1}}$ となるようと位相の動作点を的てずらす。とのように2D

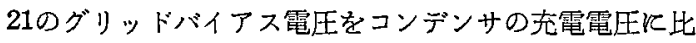
例した值て変化させプレート電圧の位相を進めプレート 電王をコンデンサ電圧の増加分だけおぎない電流の值を 一定に保つ. 使用した電解コンデンサは $250 \mu \mathrm{F}$ 単位の

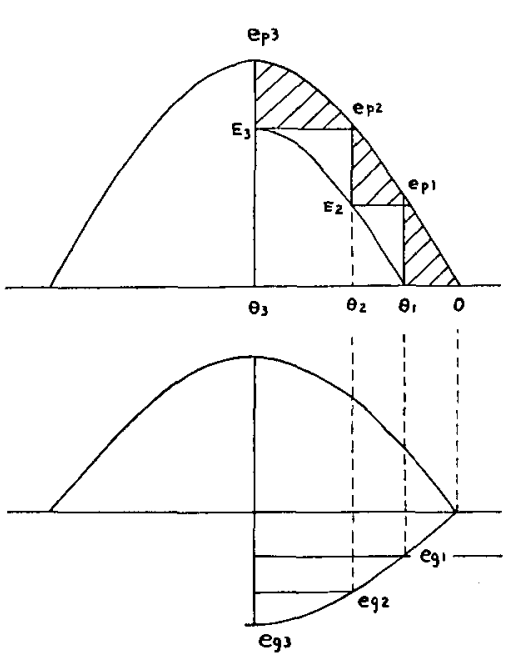

Fig. 1 Elementary diagram of constant charging current control
屯の 500 個 で全容量は $125,000 \mu \mathrm{F}$, 使用電圧は $500 \mathrm{~V}$ て蓄 積エネルギ 一は 15,625 ジュールで ある.この 電解コンデ ンサを充電 ナるのに三 相両波整流 で6本のサ イラトロン 学使用し平 均直流電流 $36 \mathrm{~A}$ 程度の定電流充電化より点溶接 1 回当りの作業時 間はほぼ 2 秒とすることができる。これにより普通なら 200KVA 以上を必要とする入力容量がわずか 40KVA と 和さ觉るととができた。電源は三相交流200Vで線電流 は充電時 100A, 充電時以外 $10 \mathrm{~A}$ である.

\section{溶接部回路}

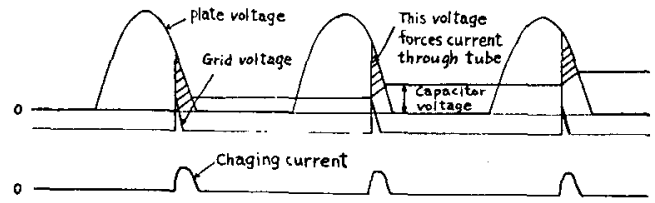

Fig. 2 Voltages and currents in rectifier (single phase)

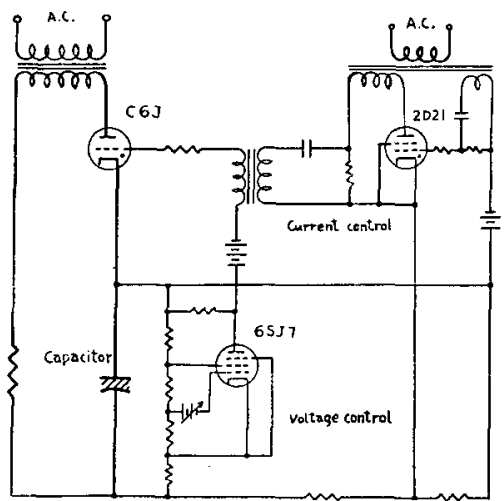

Fig. 3 Basic circuit of charging voltage and constant charging current control 充電され たコンデン サのエネル ギーは溶接 トランスを 通乙て放電 され, 二次 側に溶接電 流を流す。 溶接トラン 不変圧比 $60: 1$ 設 計され，寸 法 $400 \times 800$ $\times 900 \mathrm{~mm}$, 重量 2 トン余のもので, 150KAに拉よぶ溶接 電流を損失少く溶接回路に流すことができる。電解コン デンサは各個ごとに $0.5 \Omega$ の保護抵抗とヒューズを付け

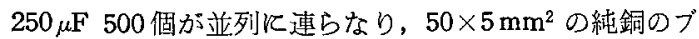
スバーで溶接トランスに接続される。スイッチにはイグ ナイトロン (MI-1200) 1 個を使い，またトランスの溶接 電流による磁気飽和を避けるため一放電ごとにりレーを 用いた極性反転装置で磁心の極性を反転させた。

二次側溶接回路は回路損失を少くするため $\mathrm{Sn}, \mathrm{Zn} 1$ \%以下を含む銅鋳物のブロックを使用した．測定による 全回路の直流抵抗值は $30 \mu \Omega$ 以下であった．また上電極 加動部柱銀面接触により摺動する銅のバーを使用してい Љ.

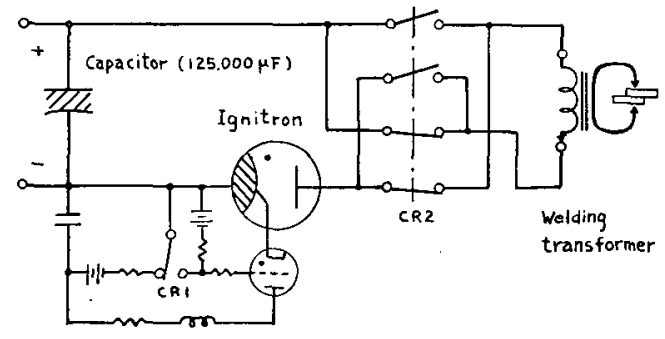

Fig. 5 Welding circuit

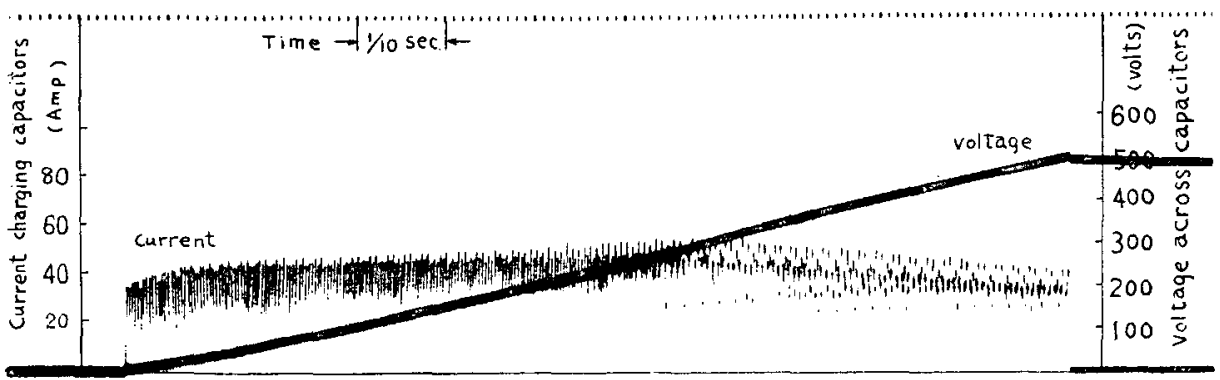

Fig. 4 Oscillogram of charging current and voltage across capacitors. $(60,000 \mu \mathrm{F})$ 


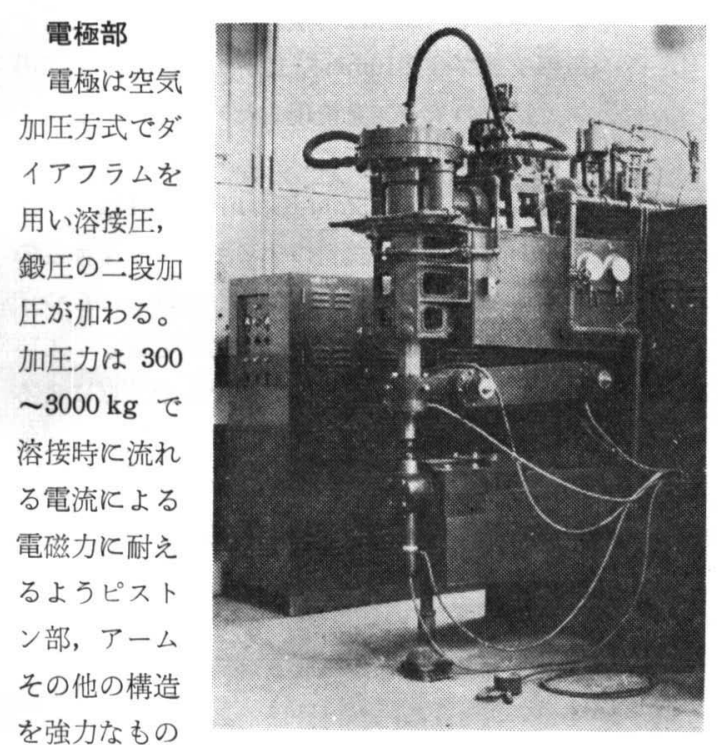

そした. 電極 Photo. 1 Spot welder which is tenチップは径30 tatively made in this research

$\mathrm{mm}$ のサイ頭円スイ形のものを使用した.

\section{3. 試作結果}

コンデンサ型点溶接機では蓄積されたエネルギーを損 失少く有効飞溶接回路に流し, その溶接能力を向上させ るととが必要である. そのため溶接回路定数括よび溶接 電流の測定を行い, また厚板試料による点溶接性能試験 を行った.

\section{溶接回路定数}

table 1 は各種測定方法による溶接二次回路定数の測 定值でインダクタンスは $1 \mu \mathrm{H}$, 直流抵抗は $30 \mu \Omega$ 以下に 怙さえられている. 抵抗值は回路導体の接触面の仕上げ の精度によって大きな差が生じるのでその值が最小とな るよう留意されている，また抵抗值は測定法の違いによ

Table 1 Resistance and Inductance of Secondary Circuit

\begin{tabular}{|c|c|c|c|c|}
\hline \multirow{2}{*}{ Measurement } & \multirow{2}{*}{$\begin{array}{c}\text { Frequency } \\
(\mathrm{c} / \mathrm{s})\end{array}$} & \multirow{2}{*}{$\begin{array}{c}\text { Resistance } \\
(\mu)\end{array}$} & \multicolumn{2}{|c|}{ Inductance $(\mu \mathrm{H})$} \\
\hline & & & circuit & Transformer \\
\hline $\begin{array}{l}\text { Wattmeter } \\
\text { method }\end{array}$ & 50 & 75.2 & 0.72 & 0.086 \\
\hline \multirow{3}{*}{$\begin{array}{l}\text { Anderson- } \\
\text { bridge } \\
\text { method }\end{array}$} & 50 & 72 & 0.66 & 0.042 \\
\hline & 500 & 500 & 0.50 & 0.028 \\
\hline & 2000 & 1055 & 0.41 & 0.024 \\
\hline $\begin{array}{l}\text { Secondary } \\
\text { current } \\
\text { wave shape }\end{array}$ & - & 109 & 0.93 & - \\
\hline $\begin{array}{l}\text { Voltage } \\
\text { drop method }\end{array}$ & d.c. & 22.7 & & \\
\hline
\end{tabular}

って溶接加圧部分の接触抵抗, 二次側短絡片の抵抗, 一 次側等価抵抗が含まれるので測定值に差が生じる．ブリ ッジ法による測定では測定周波数によって表皮効果によ る值の違いが大きい.

溶接電流波形 試作した点溶接機によるアルミニウム $3.0 \mathrm{~mm}$ 厚試料の溶接電流の測定值を尖頭電流值と時間に ついて Fig. 6 と示す. 測定はトロイダルコイルと積分 回路によって行い, 電磁オシロに記録した. 溶接条件は

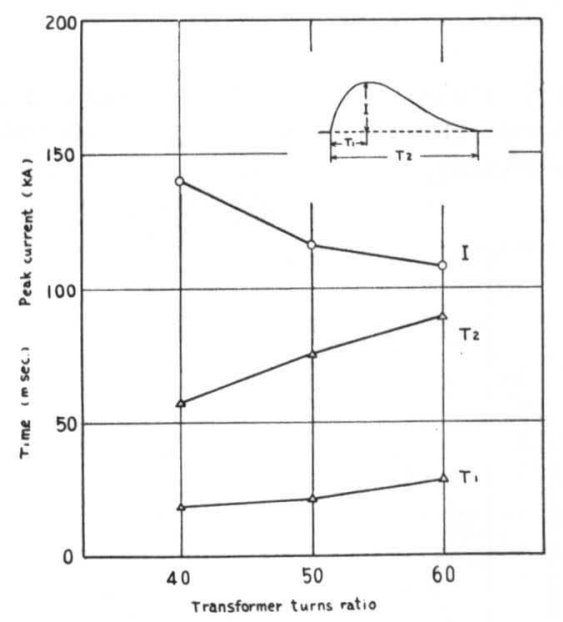

Fig. 6 Peak secondary current, time from zero to peak ard duration of secondary current ( $3.0 \mathrm{~mm} 2 \mathrm{~S}$ Aluminum, $125,000 \mu \mathrm{F}, 500$ volts)

コンデンサの静電容量 $125,000 \mu \mathrm{F}$, 電圧 $500 \mathrm{~V}$ として放 電を行い溶接トランスの変圧比は40,50,60ターンで, 波形はややオシレーションしている. 尖頭電流值は変圧 比 40 で140KAである. Fig. 7 は静電容量 $125,000 \mu \mathrm{F}$, 䉓 圧 $500 \mathrm{~V}$, 変圧比 60 の溶接条件でアルミニウム $2 \mathrm{~S}-1 / 2 \mathrm{H}$, $4 \mathrm{~mm}$ 厚板 2 板を点溶接したときの溶接電流波形括よび 板間電圧のオシログラムを示し, これから求めた抵抗值 を示している.

\section{性能試験}

溶接能力の試験をアルミニウ ム $2 \mathrm{~S}$ の試片（引張強さ13kg/ $\mathrm{mm}^{2}$ ) を使って行った. 試片の 厚さは $3 \mathrm{~mm}$ と $4 \mathrm{~mm}$ で大きさ は $30 \times 66 \mathrm{~mm}^{2}$ の 2 枚の板を点 溶接しその引張セン断強度を 5 個の平均として求め, また切断 によってナゲット断面の検査を した.

溶接条件は静電容量 125,000 $\mu \mathrm{F}$, 変圧比 60 とし, コンデンサ 電圧と電極加圧とを変化させ試 


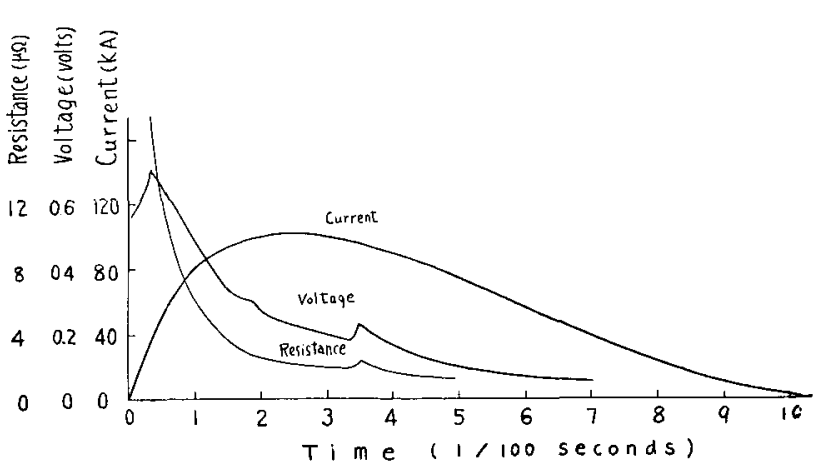

Fig. 7 Oscillogram of welding current and voltage across sheets $(4.0 \mathrm{~mm}$ 2S-Aluminum, $c=125,000 \mu \mathrm{F}, \quad \mathrm{v}=500 \mathrm{~V}$, $\mathrm{n}=60$ turns )

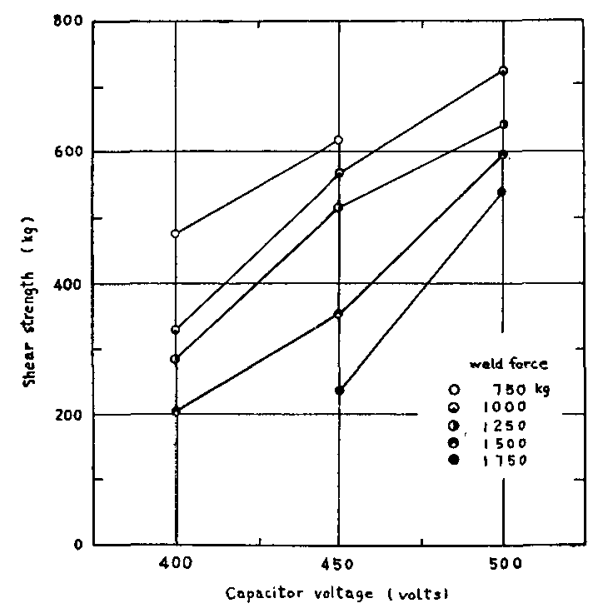

Fig. 8 Relation of static shear strength to capacitor voltage $(3.0 \mathrm{~mm} 2 \mathrm{~S}$ Aluminum, $125,000 \mu \mathrm{F}, 60$ turns)

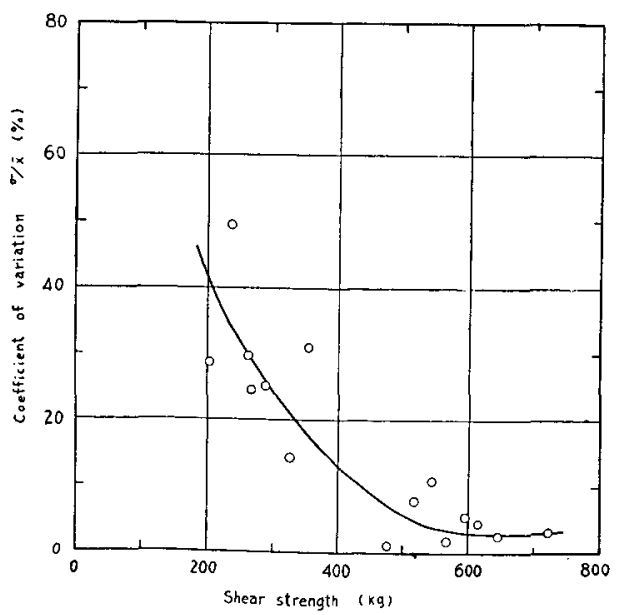

Fig. 9 Relation of percent coefficient of variation to static shear strength ( $3.0 \mathrm{~mm} 2 \mathrm{~S}$ Aluminum)
験を行った，加压は溶接加圧のみの一段で行い 電極チップは径 $16 \mathrm{~mm} \phi, 120^{\circ}$ のC形（サイ頭円 スイ班)のチップを使用した。

Fig. 8 以下の図は試験結果を示するので， Fig. 8, Fig. 9 は 3mm 厚, Fig. 10, Fig. 11 W $4 \mathrm{~mm}$ 厚のアルミ試料による引張セン断強度の 平均值と各同一条件飞敌汁る強度のばらつき を変動係数としてあらわしたものとを示してい

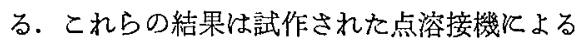
アルミニウム $2 \mathrm{~S}, 4 \mathrm{~mm}$ 厚試料の点溶接の可能 性を示しているが, $4 \mathrm{~mm}$ 厚の点溶接で電極 チップ径は1,6mmでは不足でありとび散りがあ るので $20 \mathrm{~mm}$ またはそれ以上が適当である.

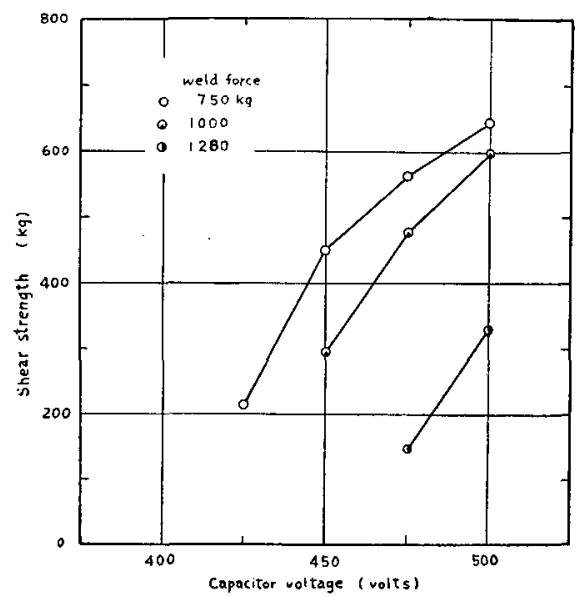

Fig. 10 Relation of static shear strength to capacitor voltage $(4.0 \mathrm{~mm} 2 \mathrm{~S}$. Aluminum, $125,000 \mu \mathrm{F}, 60$ turns)

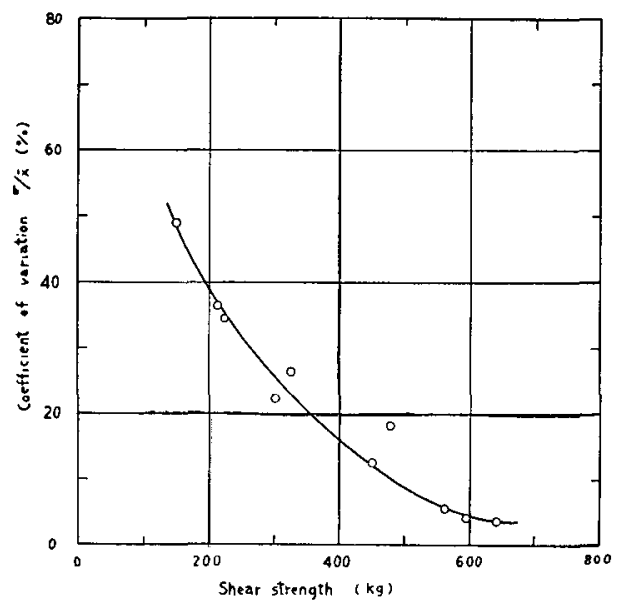

Fig. 11] Relation of percent coefficient of variation to static shear strength ( $4.0 \mathrm{~mm} 2 \mathrm{~S}$. Aluminum) 


\section{4.むすび}

低圧大容量の電解コンデンサを使いその放電を利用し た大型点溶接機の試作を行い，アルミニウム $4 \mathrm{~mm}$ 厚程 度の厚板の点溶接を行うことができた。

電解コンデンサは直流 $500 \mathrm{~V}$ 程度の比較的低圧で使用 されるので厚板の点溶接に必要なエネルギーを得るため には大容量のものを必要とする．しかしコンデンサの静 電容量が大きくなるに従い充電装置の入力容量も大きく なり充電特間も長くなるので，点溶接の作業能率を下げ ないでコンデンサの充電を行うために定電流充電方法を
考案して入力容量を大きくせず大容量電解コンデンサの 短時間充電を行いまた回路損失す少くすることができ た.

この点溶接機の試作によって最大尖頭電流值150KA程 度の溶接電流を得ることができ，車轌，建造物などに使 われるアルミニウム厚板の点溶接ができるようになり， またスタッド溶接やプロジェクション，シリーススポッ 卜溶接などによって特殊なもの0溶接にも試作された点 溶接機が使われることがわかった。

終りに本研究に対し終始御指導いたたいた本研究所主 任研究員宮田聰博士に愿く感謝いたします。

\section{研究会の動き}

12 月

特殊溶接研究委員会 A 分科会（第 1 回）

昭和35年12月 8 日 (木) 本拫学士会館に打いて開催さ れ，福田委員長以下38名が参加した。

当日の講演特よび議事は次の通りである.

1) 講 演

a 、「サブマージドアーク溶接飞拓ける溶着金属の割れ について」

石川島播磨重工業 KK 前田 豊生君

b.「自動溶接部の割れ感受性に括よぼす溶接条件の影 響」（I.I.W-XII 資料の紹介）

鉄 研 村本徹五郎君

c .「鋼板のサルファバンドと溶接割れそついて」 汽車製造 KK 大阪潮田茂男君

d. 「最近のサブマージドアーク溶接法」 大阪変王器 $\mathrm{KK}$ 木原 聰生君

e. "A Proposal Concerning the Automatic Submerged Welding Procedures for Ship's Hull”. 拉よび 「単層自動溶接施工に対する一考案とその奏用化」 川崎重工業 $\mathrm{KK}$ 岡西 達也君

f.「ASTM : A302-Cr. B の潜弧溶接飞ついて」 新三菱重工業 $\mathrm{KK}$ 神戸 高木 乙麿君

2) 議 事

a. I.I.W-XII Circular letter 飞ついて鉄研村本幹事よ り紹介がありその主内容であるサブマージドアーク 溶接用フラックスの共同試験に日本が参加するか否 か討議され，その結果時期尚早であるとして参加し ないことに決定した。

b. I.I.W., J.I.W. の関係飞ついて検討され，J.I.W. 12 委員会の活動方針がいまだ明確になっていない現状 であるので，中根 A 分科会主査が I.I.W.-XII Sub Comm. A の連絡者となり, I.I.W. へもその旨通知 することになった.

\section{溶接冶金研究委員会}

日 時 昭和35年12月17日 $10.00 \sim 16.30$

場 所 石川舁播磨重工業 KK 豊洲ビル会議室

出席者 関口委員長以下31名

講 演

1）「銟の溶接に招ける水素についての諸問題」 鉄 研 安藤 精一君
2 ）「被覆溶接棒の脱酸反応」

3) 特別講演

神戸製鋼所柇䳆千代君

「耐熱材料の溶接の問題点」

石川息播磨重工KK 中村 素君

4)「アルミニウムの溶接に和ける水素」 原 研 藤村 理人君

5）「ジルコニウムおよびその合金の溶接雰国気が溶接 結果に及保す影響について」

材技研松田 福久君 次回のテーマは「高温性能」とし計画立案は担当幹事 に依頼することになった.

\section{J.I.W.-IX 委員会}

日 時 昭和 36 赁12月 7 日 $10.00 \sim 15.00$

場 所 東大船舶工学科学生図書室

出席者 吉識委員長以下18名

議 事

I.I.W. 1961年度大会第 9 委員会への出席者括よび提出 論文について検討し次の通り決定した.

1. 出席者（略）

2. 提出論文

1）「高温予企が鋼の残留延性におよぼす影響」

寺沢一婎, 大谷碧, 吉田俊雄, 寺开清

2）「高温予歪が鋼の切久脆性に执よぼす影響」 大阪大学工学部, 川崎重工業 $\mathrm{KK}$

3) 「厚板調犋 $\mathrm{HT}-80$ 高張力鋼 ( $\mathrm{K}-0$ 鋼) の工作性に 関する研究: 川崎重工業 KK

4)「再現熱影響部延性試験による高張力鋼の溶接性の 評価」

5）「高張力鋼の溶接割れ試験について」

木原博，鈴木春義，中村治方

その他，参考盗料として "Researches on Brittle Fracture Mechanism” by T. Kanazawa Mr. Lagasse 宛 送付することになった。

なお，1960年度 I.I.W.-IX 委員会で審議された "Co-operative Study of Brittle Fracture in Service" は, 関係学協会に紹介し拹力を求めることになった.

\section{J.I.W.-IX.「溶接割れ試験」特別小委員会}

日 時 昭和35年12月 9 日 場 所 造船協会々議室

I.I.W. Doc. IX-273-60 "Study of Weldability TestInformation to be gathered on cracking tests" $飞$ 対 る日本側の回答を作成した。 